\title{
Author Correction: Massively parallel in vivo CRISPR screening identifies RNF20/40 as epigenetic regulators of cardiomyocyte maturation
}

\author{
Nathan J. VanDusen (D), Julianna Y. Lee, Weiliang Gu, Catalina E. Butler (D), Isha Sethi, Yanjiang Zheng, \\ Justin S. King (1), Pingzhu Zhou, Shengbao Suo, Yuxuan Guo (D), Qing Ma, Guo-Cheng Yuan \& William T. Pu
}

Correction to: Nature Communications https://doi.org/10.1038/s41467-021-24743-z, published online 21 July 2021.

The original version of this Article contained an error in the spelling of the author William T. Pu, which was incorrectly given as William William Pu. This has now been corrected in both the PDF and HTML versions of the Article.

Published online: 19 August 2021

\footnotetext{
(c) Open Access This article is licensed under a Creative Commons Attribution 4.0 International License, which permits use, sharing, adaptation, distribution and reproduction in any medium or format, as long as you give appropriate credit to the original author(s) and the source, provide a link to the Creative Commons license, and indicate if changes were made. The images or other third party material in this article are included in the article's Creative Commons license, unless indicated otherwise in a credit line to the material. If material is not included in the article's Creative Commons license and your intended use is not permitted by statutory regulation or exceeds the permitted use, you will need to obtain permission directly from the copyright holder. To view a copy of this license, visit http://creativecommons.org/licenses/by/4.0/.
}

(C) The Author(s) 2021 